\title{
Liter per Meter Squared
}

National Cancer Institute

\section{Source}

National Cancer Institute. Liter per Meter Squared. NCI Thesaurus. Code C120814.

A unit of concentration equal to liter per meter squared. 